\title{
KESADARAN HUKUM MASYARAKAT DALAM JUAL BELI TANAH DENGAN AKTA PPAT DI KECAMATAN TINANGGEA KABUPATEN KONAWE SELATAN SULAWESI TENGGARA
}

\author{
Rifan Agrisal Ruslan*, Umar Ma'ruf ${ }^{* *}$ \\ * Mahasiswa Program Magister (S2) Kenotariatan Fakultas Hukum UNISSULA email: faizulkhakim@gmail.com \\ ** Dosen Fakultas Hukum UNISSULA
}

\section{ABSTRACT}

The purpose of writing in this study is the first, to know and analyze factors Some people in Tinanggea Sub-District South Konawe Regency of Southeast Sulawesi that has not yet had legal awareness in the act of buying and selling land ownership in the presence of PPAT. Second, To know and Analyze Efforts - Local Government efforts in awakening the community in District Tinanggea South Konawe Southeast Sulawesi against the sale and purchase of land ownership in the presence of PPAT. Third To know to be done in order to Maasyarakat in Tinanggea Sub-District of Konawe Selatan Regency in Sulawesi Teggara performs the sale and purchase of land ownership in the presence of PPAT.

The approach method used in this research is empirical juridical. Juridically, this research is based on the rule of law of Basic Agrarian Law and Government Regulation Number 37 Year 1998 juncto Government Regulation Number 24 Year 2016. Empirically, this study aims to know about the rules related to the transfer of land rights with the fact that occurred that deviate from the rules that prevail in the District Tinanggea South Konawe Southeast Sulawesi. Specification of Research that is the object of research is the plot of land is the transfer of Rights to Land with the act of buying and selling of land ownership in the presence of PPAT conducted. Sources and Techniques Data collection is primary data obtained from interviews conducted by 30 respondents and secondary data obtained from the opinions of scholars and literature review. Then Theory in use is Position Theory, Authority Theory and Theory of Legal Certainty.

From the results of research can be concluded that the legal consciousness of the people of Tinanggea Sub-District of South Konawe Regency of Southeast Sulawesi is related to the transfer of land rights due to the sale and purchase of land ownership in the presence of the First PPAT: Caused by lack of PPAT and PPATS in the community, which is set by the competent authorities, Caused by a very high kinship and Due to a very low legal community awareness. The second is the government's efforts in the form of socialization held by the local revenue agency related Value Object Tax (NJOP), Tinanggea sub-district office along with jejerannya Kelurahan and village appealed and made a place for reporting / consultation related to the transfer of rights of Sale and Purchase of Land, Cooperation undertaken by Tinanggea Subdistrict Sub-District and Village that make the Letter of Statement of Physical Land Mastery (SPPFT) that the letter is known by Kecamatan Kelurahan and Desa. The third is: The ideal concept of the author's research is the legal counseling to the public to grow knowledge to the public about the importance of legal awareness of the act of buying and selling land ownership in the presence of PPAT, Socialization of the sale and purchase of land ownership in the presence of PPAT. As a form of government service to the public in awakening the rights and obligations of the people in the eyes of the law and Data Collection and the making of Land Book is aimed to record and provide a legal protection for the community so that no land grab or land disputes.

Keywords: Legal Awareness, Sale and Purchase, Tinanggea Sub-district.

\section{PENDAHULUAN}

Negara Indonesia adalah salah satu negara terluas di dunia dengan total luas negara 5.193.250 $\mathrm{km}^{2}$ (terdiri dari lautan dan daratan). ${ }^{1}$ Yang

\footnotetext{
$1 \quad$ http://www.invonesia.com/luas-wilayah-negara-
} indonesia.html di akses pada tanggal 08 April 2017. kemudian mempunyai batas wilayah tanah di masing-masing wilayahnya. Tanah di seluruh wilayah Indonesia sebagai karunia Tuhan Yang Maha Esa kepada rakyat Indonesia, yang bersatu menjadi bangsa Indonesia merupakan salah satu unsur utama bagi kelangsungan hidup dan penghidupan bangsa Indonesia sepamjang masa, tujuannya 
adalah dipergunakan untuk tercapainya sebesarbesarnya kemakmuran rakyat yang terbagi secara adil dan merata baik materil maupun spirit sebagaimana dinyatakan dalam Pasal 33 ayat (3) Undang-Undang Dasar 1945, yang isinya: " Bumi, air, dan kekayaan alam yang terkandung di dalamnya dikuasai oleh negara dan dipergunakan sebesarbesarnya bagi kemakmuran rakyat."

Negara Indonesia terkenal dengan negara agraris yang kebanyakan atau mayoritas penduduknya bercocok tanam sebagian untuk mata pencarian hidup sehari-hari. Disamping itu tanah juga digunakan sebagai lahan pembangunan utuk gedung perkantoran, pertokoan, industri, serta merupakan tempat tinggal manusia. ${ }^{2} \mathrm{Hak}$ milik tanah sangat penting bagi Negara, bangsa dan rakyat Indonesia sebagai masyarakat agraris yang sedang membangun. Akan tetapi tanah yanag merupakan sumber kehidupan pokok dan mendasar bagi manusia. $^{3}$

Tanah adalah bagian yang terdapat pada kerak bumi yang tersusun atas mineral dan bahan organik. Tanah merupakan salah satu penunjang yang membantu kehidupan semua mahluk hidup yang ada di bumi. Tanah sangat mendukung terhadap kehidupan tanaman yang menyediakan hara dan air di bumi. selain itu, Tanah juga merupakan tempat hidup berbagai mikroorganisme yang ada di bumi dan juga merupakan tempat berpijak bagi sebagian mahluk hidup yang ada di darat. Didalam kehidupan manusia Tanah merupakan salah satu bagian terpenting yang terkadang sering menimbulkan masalah tentang batas-batas dan wilayah-wilayah yang telas dikuasai oleh manusia itu sendiri.

Tanah adalah bagian yang terdapat pada kerak bumi yang tersusun atas mineral dan bahan organik. Tanah merupakan salah satu penunjang yang membantu kehidupan semua mahluk hidup yang ada di bumi. Tanah sangat mendukung terhadap kehidupan tanaman yang menyediakan hara dan air di bumi. selain itu, Tanah juga merupakan tempat hidup berbagai mikroorganisme yang ada di bumi dan juga merupakan tempat berpijak bagi sebagian mahluk hidup yang ada di darat. Didalam kehidupan manusia Tanah merupakan salah satu bagian terpenting yang terkadang sering menimbulkan masalah tentang batas-batas dan wilayah-wilayah

\footnotetext{
${ }^{2}$ Boedi Harsono, 2003, Hukum Agraria Indonesia, Djambatan, Jakarta, hlm. 5.

3 Samun Ismaya, 2013, Hukumm Administrasi Pertanahan, Graha Ilmu, Yogyakarta, hal. 21.
}

yang telas dikuasai oleh manusia itu sendiri.

Menanggapi arti penting masalah tanah dalam kehidupan ini maka diperlukan peraturan yang mengatur tentang tanah. Sehingga pemerintah mengeluarkan perarturan yaitu Undang-Undang Nomor 5 Tahun 1960 Tentang Peraturan Dasar Pokok Agraria (UUPA) dimana dalam Pasal 4 ayat (1) berbunyi: " Atas dasar hak menguasai dari negara sebagai yang dimaksud dalam Pasal 2 ditentukan adanya macam-macam hak atas permukaan bumi, yang disebut tanah yang dapat diberikan kepada dan dipunyai oleh orang-orang serta badan-badan hukum."

Mengingat besarnya peranan hak-hak atas tanah yang meningkatkan harga tanah, maka dengan adanya UUPA yang diberlakukan oleh Mentri Dalam Negeri (sekarang BPN) seperti yang kita lihat dalam Pasal 26 ayat (1) UUPA, menyatakan: " Jual Beli, Hibah, Pemberian Warisan, Pemberian Wasiat, Pemberian Menurut Adat dan Perbuatan-Perbuatan lain yang dimaksudkan untuk memindahkan hak milik serta pengawasannya diatur dengan Peraturan Pemerintah."

Untuk menjamin kepastian hukum dan kepastian ha katas tanah oleh pemerintah diatur dalam Peraturan Pemerintah Nomor 10 Tahun 1961 yang disempurnakan dengan Peraturan Pemerintah Nomor 24 Tahun 1997, yaitu tentang Pendaftaran Tanah. Peraturan Pemerintah tersebut dikeluarkan sebagai usaha pencegahan terhadap bentuk-bentuk perbuatan hukum yang sering terjadi dalam masyarakat. Pada hakekatnya bentuk perbuatan hukum tersebut justru menyimpang atau melanggar hukum yang berlaku, yang apabila dibiarkan akan mengganggu tercapainya program tata tertib dalam bidang pertanahan, yaitu tertib hukum pertanahan, tertib administrasi pertanahan, tertib pemilikan/ penguasaan tanah dan tertib penggunaan serta pemeliharaan kesuburan tanah.

Peralihan hak atas tanah dan hak milik atas satuan rumah susun melalui jual beli, tukar menukar, hibah, pemasukan data perusahaan dan perbuatan hukum pemindahan hak lainnya, kecuali pemindahan hak melalui lelang hanya dapat didaftarkan jika dibuktikan dengan akta yang dibuat oleh Pejabat Pembuat Akta Tanah(PPAT) yang berwenang menurut ketentuan peraturan perundang-undangan yang berlaku.

Menurut Boedi Harsono, ada dua macam sistem pendaftaran tanah ialah sistem pendaftaran akta (registration of deeds) dan sistem pendaftaran hak 
(registration of titles). Sistem pendaftaran tanah mempermasalahkan : apa yang didaftar, bentuk penyimpanan dan penyajian data yuridisnya serta bentuk tanda bukti haknya.

Sistem pendaftaran akta (registration of deeds) dan sistem pendaftaran hak (registration of titles). Sistem pendaftaran tanah mempermasalahkan : apa yang didaftar, bentuk penyimpanan dan penyajian data yuridisnya serta bentuk tanda bukti haknya baik dalam sistem pendaftaran akta maupun dalam sistem pendaftaran hak, akta merupakan sumber data yuridis. Dalam sistem Pendaftaran akta, aktaakta inilah yang didaftar. Dalam sistem pendaftaran akta, pejabatnya bersikap pasif. Ia tidak melakukan pengujian kebenaran data yang disebut dalam akta yang didaftar. Di kantor Pejabat Pendaftaran Tanah (PPAT), salinan akta disimpan danterbuka untuk umum, sedangkan pemilik hak diberikan tanda bukti berupa asli atau minuta akta tersebut.

Pembuktian bahwa hak atas tanah tersebut dialihkan, maka harus dibuktikan dengan suatu akta yang dibuat oleh dan dihadapan Pejabat Pembuat Akta Tanah disebut PPAT yaitu akta jual beli yang kemudian akan dijadikan dasar pendaftaran perubahan data pendaftaran tanah sebagaimana dimaksud dalam ketentuan Pasal 95 ayat 1 huruf a Peraturan Menteri Agraria/Kepala Badan Pertanahan Nasional Nomor 3 Tahun 1997. Akta Jual Beli yang dibuat dihadapan Pejabat Pembuat Akta Tanah disebut PPAT tersebut bertujuan untuk memberikan kepastian hukum kepada pemegang hak atas suatu bidang tanah (pembeli tanah). Menurut R. Tresna menyatakan, "pada umumnya akta itu adalah suatu surat yang ditandatangani, memuat keterangan tentang kejadian-kejadian atau hal-hal yang merupakan dasar dari suatu hak atau suatu perjanjian, dapat dikatakan bahwa akta itu ialah suatu tulisan dengan mana dinyatakan sesuatu perbuatan hukum". 4

Akta tanah yang dibuat oleh dan dihadapan Pejabat Pembuta Akta Tanah disebut PPAT, merupakan alat bukti atas dilaksanakannya suatu perbuatan hukum tertentu, sehingga perbuatan hukum pengalihan hak atas tanah dapat di daftarkan pada Kantor Pertanahan setempat. Tidak dapat dipungkiri, bahwa banyak sengketa tanah timbul karena dokumen-dokumen pertanahannya yang tidak sempurna. Oleh karena itu, Pejabat Pembuat

${ }^{4}$ R. Tresna, 1993, Komentar HIR, Pradanya Paramita, Jakarta, hlm.142.
Akta Tanah disebut PPAT perlu dibekali dengan pengetahuan tentang hukum beserta segala aspeknya, yang berkaitan dengan masalah pertanahan. $^{5}$

Dewasa ini sengketa-sengketa tanah yang terjadi lebih kepada tanah yang digunakan untuk proyek pembangunan seperti real estate, pariwisata,pertambangan, pembangunan jalan, bendungan, kawasan industri, serta lapangan golf. Demikian pula kebanyakan dari sengketa tanah itu berkaitan dengan pertentangan hak dan kepentingan antara penduduk lokal dengan kekuatankekuatan luar yang berusaha keras mencari keuntungan komersial dari proyek-proyek tersebut.

Pada banyak kasus, kepentingan penduduk asli atau penggarap tanah sering dikorbankan atas nama kepentingan umum demi pembangunan,karena kurangnya atau lemahnya pengakuan hukum terhadap tanah tersebut. Kerentanan terhadap pengakuan pemilikan tanah penduduk asli maupunpenggarap tanah telah terjadi sejak periode kolonial Belanda, sehingga maraknya sengketa tanah saat ini memiliki akar sejarah yang panjang. ${ }^{6}$

Sengketa tanah selain timbul karena dokumendokumen pertanahan yang tidak sempurna, juga diakibatkan oleh ketidak cermatan Pejabat Pembuat Akta Tanah disebut PPAT dalam pembuat akta-akta pemindahan hak atas tanah. Menurut Rusmadi Murad, sengketa tanah atau dapat juga dikatakan sebagai sengketa hak atas tanah, yaitu : " Timbulnya sengketa hukum yang bermula dari pengaduan sesuatu pihak (orang atau badan) yang berisi keberatan-keberatan dan tuntutan hak atas tanah, baik terhadap status tanah, prioritas, maupun kepemilikannya dengan harapan dapat memperoleh penyelesaian secara administrasi sesuai dengan ketentuan peraturan yang berlaku.

Kasus pertanahan itu timbul karena adanya klaim/pengaduan/keberatan dari masyarakat (perorangan/badan hukum) yang berisi kebenaran dan tuntutan terhadap suatu keputusan Tata Usaha Negara di bidang pertanahan yang telah ditetapkan oleh Pejabat Tata Usaha Negara di lingkungan Badan Pertanahan Nasional, serta keputusan Pejabat tersebut dirasakan merugikan hak-hak merekaatas

5 Ali Achmad Chomzah, 2004, Hukum Agraria (Pertanahan) Indonesia, Jilid I,Prestasi Pustakarya, Jakarta, hlm 23.

${ }^{6}$ Kano Hiroyoshi, 1997, Tanah dan Pajak, Hak Milik dan Sengketa Agraria, Pustaka Sinar Harapan, Jakarta, hal. 31 . 
suatu bidang tanah tersebut.

Dibidang pertanahan dalam menghadapi kasuskasus konkrit, selain tersedianya perangkat hukum diperlukan juga tersedianya berbagai keterangan mengenai tanah yang menjadi obyek perbuatan hukum.Keterangan mengenai tanah tersebut dapat ditinjau dari 2 (dua) segi, yaitu :dari segi fisik, tanah diperlukan adanya kepastian mengenai letak, batasbatasdan luasnya serta pemilikan bangunan dan tanaman yang mungkin adadiatasnya. Dari segi yuridis, diperlukan adanya kepastian mengenai statushukum tanahnya, pemegang haknya dan atau tidak adanya hak yangmembebaninya. ${ }^{7}$

Dengan adanya klaim tersebut, mereka ingin mendapat penyelesaian secara administrasi dengan apa yang disebut koreksi serta merta dari Pejabat yang berwenang untuk itu. Kewenangan untuk melakukan koreksi terhadap suatu keputusan Tata Usaha Negara di bidang pertanahan(sertifikat/Surat Keputusan Pemberian Hak Atas Tanah), ada pada Kepala Badan Pertanahan Nasional. ${ }^{8}$

Kemudian dapat juga diakibatkan oleh orang atau badan hukum itu sendiri dalam melakukan suatu perbuatan hukum terentu, yang berobyekan tanah, belum memenuhi persyaratan dengan peraturan perundang-undangan. Berdasarkan ketentuan Pasal 37 ayat (1) Peraturan Pemerintah Nomor 24 Tahun 1997 disebutkan, bahwa: " Peralihan hak katas tanah dan hak milik atas satuan rumah susun melalui jual beli, tukar menukar, hibah, pemasukan dalam perusahaan dan perbuatan hukum pemindahan hak lainnya kecuali pemindahan hak melalui lelang hanya dapat di daftarkan jika dibuktikan dengan akta yang dibuat oleh PPAT yang berwenang menurut ketentuan peraturan perundang-undangan yang berlaku."

Berdasarkan peraturan pemerintah tersebut pemegang hak atas tanah wajib mendaftarkannya pada Kantor Pertanahan setempat. Menurut ketentuan Pasal 6 ayat (2) Peraturan Pemerintah Nomor 24 Tahun 1997 , menyatakan: Dalam melaksanakan pendaftaran tanah, Kepala Kantor Pertanahan dibantu oleh PPAT dan pejabat lain yang ditugaskan untuk melaksanakan kegiatan-kegiatan

7 Budi Harsono, 2003, Hukum Agraria Indonesia, Sejarah pembentukan Undang - Undang Pokok Agraria, Isi dan Pelaksanaannya, Jilid II, Djambatan, Jakarta, hlm. 29.

${ }^{8}$ Rusmadi Murad, 2006, Penyelesaian Sengketa Hukum Tanah,PT.Alumni, Jakarta, hlm 89-90. tertentu menurut peraturan pemerintah ini dan peraturan perundang-undangan yang berlaku."

Akta otentik yang merupakan bukti yang lengkap (mengikat) berarti kebenaran dari hal-hal yang tertulis dalam akta tersebut dianggap sebagai benar, selama kebenarannya itu tidak ada pihak lain yang dapat membuktikan sebaliknya. ${ }^{9}$

Kewenangan Pejabat Pembuat Akta Tanah (PPAT) berkedudukan sebagai pembantu Kepala Kantor Pertanah dalam melaksanakan tugas sebagaian pendaftaran tanah yaitu dengan membuat akta atas perbuatan hokum pemindahan ha katas tanah yang selanjutnya dipergunakan sebagai dasar pendaftaran tanah. Istilah Pejabat Pembuat Akta Tanah (PPAT) sudah dikenal sejak berlakunya Peraturan Pemerintah Nomor 10 Tahun 1961 tantang Pendaftaran Tanah, yang merupakan peraturan pelaksanaan Undang-Undang Nomor 5 Tahun 1960 tentang Peraturan Dasar Pokok-Pokok Agraria atau lebih dikenal Undang-Undang Pokok agraria (UUPA).

Pejabat Pembuat Akta Tanah (PPAT) sebagaimana disebutkan dalam Pasal 1 ayat (1) Peraturan Pemerintah Nomor 37 Tahun 1998 Juncto Pasal 1 ayat (1) Peraturan Pemerintah Nomor 24 Tahun 2016, ialah: " Pejabat Pembuat Akta Tanah selanjutnya disebut PPAT adalah pejabat umum yang diberi kewenangan untuk membuat akta-akta otentik mengenai perbutan hukum tertentu mengenai hak atas tanah atau hak milik atas satuan rumah susun."

Mengenai siapa yang dapat diangkat sebagai PPAT berdasarkan ketentuan Pasal 6 huruf (f) Peraturan Pemerintah Nomor 37 Tahun 1998 adalah : " Lulusan program pendidikan spesialis notariat dan program magister kenotariatan atau program pendidikan khusus PPAT yang diselenggarakan oleh lembaga pendidikan tinggi. "

Dengan demikian, PPAT merupakan pejabat umum yang diangkat atau ditunjuk oleh pemerintah yang berwenang dalam pembuatan akta-akta otentik. Sehingga pemindahan hak atas tanah yang dilakukan tanpa melalui PPAT, adalah tidak memenuhi persyaratan formil dan juga tidak sesuai dengan prosedur hukum yang berlaku.

Hal demikian dapat menimbulkan suatu akibat hukum. Akta yang dibuat tidak melalui PPAT tidak terjamin kekuatan hukumnya, lain halnya jika akta pemindahan hak atas tanah dilakukan di hadapan PPAT, maka akta tersebut merupakan akta otentik,

${ }^{9}$ Teguh Samudera, 2004, Hukum Pembuktian dalam Acara Perdata, Edisi Pertama, PT. Alumni, Bandung, hlm.49 
yang merupakan alat pembuktian atas suatu perbuatan hukum tersebut. Akan tetapi, pada masyarakat kita yang sudah maju dengan perkembangan budaya kehidupan perkotaan masih banyak yang kurang sadar akan pentingnya jaminan kepastian hukum.

Hal ini sering kali dijumpai di masyarakat kecamatan Tinanggea Kabupaten Konawe Selatan, dalam melakukan proses pemindahan hak atas tanah masih menggunakan nota/kuwitansi pembelian yang kepastian hukumnya tidak terjamin dan tanpa melalui PPAT sebagai pejabat yang bewenang dalam hal tersebut. Tentunya banyak faktor yang menyebabkan masyarakat melakukan pemindahan hak atas tanah tanpa melalui PPAT.

\section{METODE PENELITIAN}

Berdasarkan perumusan masalah dan tujuan penelitian maka metode pendekatan yang digunakan adalah metode pendekatan yuridis empiris. Yuridis artinya menggunakan norma-norma hukum yang bersifat menjelaskan dengan cara meneliti dan pembahasan peraturan-peraturan hukum yang berlaku saat ini, sedangkan arti dari kata empiris adalah melakukan penelitian di lapangan dengan observasi dan wawancara untuk membandingkan peraturan yang berlaku dengan kenyataan yang terjadi dalam masyarakat.

Spesifikasi penelitian ini adalah penelitian deskriptif analitis, yaitu suatu penggambaran terhadap berbagai permasalahan yang menjadi obyek penelitian dan memberikan suatu kesimpulan yang tidak bersifat umum.

Lokasi penelitia di wilayah Kabupaten Konawe Selatan terletak di Propinsi Sulawesi Tenggara Konsel mempunyai 25 kecamatan dengan 346 desa dan 17 kelurahan.

Berdasarkan jenis data yang peneliti ambil maka pengumpulan data penelitian ini yakni: Data primer, dilakukan dengan cara wawancara. Dalam hal ini penulis mengadakan wawancara kepada responden yaitu Camat Tinanggea Kabupaten Konawe Selatan, Kepala Desa Kecamatan Tinanggea dan Masyarakat Kecamatan Tinanggea yang berjumlah 30 Responden. Data sekunder, dilakukan dengan cara studi / kajian pustaka (bahan pustaka), serta studi pendapat para sarjana dan literature-literature.

Tujuan analisis data adalah Data yang diperoleh, baik dari studi lapangan maupun studi pustaka pada dasarnya merupakan data tataran yang dianalisis secara deskriptif kualitatif, yaitu data yang terkumpul dituangkan dalam bentuk uraian logis dan sitematis.

\section{HASIL PENELITIAN DAN PEMBAHASAN}

Pelaksanaan Pemindahan kepemilikan tanah karena Jual Beli Hak atas Tanah dimasyarakat Kecamatan Tinanggea sebagian besar penyebab tidak melakuukan perpindahan hak milik tanah pada pejabat yang berwenang, faktor-faktor penyebabnya ialah faktor penyebab kurngnya PPAT dan PPATS, faktor penyebab biaya yang mahal, faktor penyebab karena kekeluargaan yang sangat kuat dan faktor penyebab kesadaran hukum masyarakat yang sangat rendah.

Berdasarkan wawancara dengan Ivan Ardiansyah, S.STP, selaku Camat Tinanggea dan sekaligus Pejabat Pembuat Akta Tanah Sementara ( PPATS ) di Kabupaten Konawe Selatan, ialah harusnya masyarakat lebih mencari pemerintah dan pejabat yang berwenang dalam perpindahan hak milik atas tanah agar kepastian hukumnya itu terjamin dan tidak ada masalah dikemudian harinya. ${ }^{10}$

Pada umumnya berbicara sadar atau tidak sadarnya, masyarakat yang berada di Kecamatan Tinanggea Kabupaten Konawe Selatan tentang jual beli tanah di hadapan PPAT. Haruslah terlebih dahulu mengklasifikasi umur pada masyarakat di Kecamatan Tinanggea ialah Kalangan umur anak Dewasa 23-49 Tahun dan Kalangan Umur >50 Tahun. Di kalangan Dewasa $60 \%$ persen sudah banyak yang memahami tentang Jual Beli Tanah di hadapan PPAT dari Angka $100 \%$ persen. Karena di Kalangan dewasa mereka mempunyai pendidikan yang bisa dibilang sangat baik.

Sedangkan yang usianya yaitu >50 tahun keatas masih banyak yang tidak berpendidikan sama sekali dan tingkat pemahamannya tentang Jual Beli Tanah di hadapan PPAT 70\% dari angka $100 \%$ persen.

Salah satu contoh kasus tentang sengketa tanah warisan yang sering kali terjadi di Kecamatan Tinanggea ialah ayah dan ibu A mempunyai 2 orang anak laki-laki. Pada tahun 2014 ayah dan ibu A meninggal karena tabrakan yang menigalkan warisan

10 Wawancara, Ivan Ardiansyah, S.STP, Camat Tinanggea dan Pejabat Pebuat Akta Tanah Sementara, 9 Juli 2017 
dua bidang tanah. Satu bidang tanah berisi rumah serta tempat tinggal mereka berdua yaitu tanah hasil perkawinan ayah dan ibu si A. Dan satu bidang tanahnya lagi berisi perkebunan Kopi yang belum sempat dibagikan oleh ayah dan ibu si A pada saat ia meninggal. Kemudian anak tertua dari ayah dan ibu si A itu menjual kepada keluarganya tanpa sepengetahuan adiknya dan pemerintah setempat.

Kemudian Enam Bulan sepeninggalan ayah dan ibu $A$, anak kedua dari almarhum dan almarhumma atau adik dari kaka $A$, yang menjual tanah tersebut mengetahui dikarenakan sewaktu ke kebun kopi melihat bahwa yang mengelola kebun kopinya adalah keluarganya dan ia pun bertanya. Setelah ia bertanya ia mengetahui bahwa kebun kopi milik almarhum ayah dan almarhumma ibu nya sudah di jual oleh kakaknya. Setelah itu terjadilah masalah antara keduanya dan melibatkan pemerintah yang tidak tau sama sekali kronologi jual beli di bawah tangan tersebut. Inilah kasus yang sering kali terjadi di Kecamatan Tinanggea, dan seketika pemerintah diminta untuk menyelesaikannya maka ia memanggil seluruh pihak keluarga yang berada dalam konflik dan menyelesaikannya secara kekeluargaan.

Minimnya Pejabat Pembuat Akta Tanah membuat warga dikonsel tidak jual beli sesuai prosedur terhadap Pejabat Pembuat Akta Tanah pun masih belum ada di tambah lagi Pejabat Pembuat Akta tanah Sementara itu juga belum terlantik, yang sudah mengajukan berkas dan permohonan pelantikan oleh Kantor Badan Pertanahan. Serta biaya yang sanggat mahal membuat masyarakat Kecamatan Tinanggea melakukan jual beli di bawah tangan dengan alasan tingkat biaya yang di keluarkan ketika menggunakan pejabat yang berwenang atau Pejabat Pembuat Akta Tanah itu sangat membutuhkan biaya yang mahal sehingga masyarakat tidak mampu untuk membayarnya. Dan adapula yang mengatakan karena jual beli yang mereka lakukan itu hanya kepada keluarga. Maka mereka beranggapan dikemudian hari tidak mungkin ada permasalahan dan meskipun ada permasalahan mereka akan selesaikan secara kekeluargaan.

Dalam hal perbandingan tentang sadar dan tidak sadarnya masyarakat tentang Jual Beli Tanah di hadapan PPAT, sudah $65 \%$ persen dari pengabungan antara kalangan dewasa 23-49 tahun dan $>50$ Tahun keatas yang terbilang faham. Kemudian $35 \%$ persen lainnya pengabungan antara dewas 23-49 tahun yang tidak berpendidikan dan
$>50$ tahun yang terbilang belum faham.

Upaya harus dibuat oleh pemerintah sebagai Penangung jawab terhadap kemakmuran rakyatnya memiliki tanggung jawab besar dalm upaya memikirkan dan mewujudkan terbentuknya pelestarian lingkungan hidup. ${ }^{11}$ Kesadaran akan pentingnya Pemahaman Masyarakat tentang Jual Beli Tanah di hadapan PPAT harus di tumbuhkan pada rakyat bukan hanya pada kalangan pemerintah melaikan kaum rakyat yang berada dibawah pemerintahan juga wajib diberikan pemahaman.

Jadi kebanyakan di dalam prakteknya budaya-budaya yang berkembang di kehidupan masyarakat adalah budaya yang tidak sewajarnya di mata hukum. Oleh karenanya banyak perbuatanperbuatan masyarakat yang sangat menyimang dari aturan hukum.

Pelaksanaan pemerintah daerah dalm upaya menyadarkan masyarakat terkhusus di Kecaatan Tinangge Kabupaten Konawe Selatan antara Kantor Pertanahan, Kantor Dinas Pendapatan Daerah, Kantor Kecamatan Tinaggea beserta jejerannya Kantor Lurah dan desa itu saling bekerja sama dan bekoordinasi. Upaya yang dilaksanakan oleh pemerintah tersebut ialah sosialisasi Dinas Pendapatan Daerah yang berkerjasama dengan kecamatan tinanggea Kabupaten konawe selatan terkait Nilai Objek Pajak ( NJOP), Kantor kecamatan bekerjasama dengan lurah dan desa untuk menghimbau masyarakat dalam perbuatan jual beli tanah untuk memberitahukan dan melaporkan kepada pemerintah agar tidak ada perselisihan dikemudian hari dan Kecamatan dan lurah serta desa bekerjasama membuat Surat Pernyataan Penguasaan Fisik Tanah (SPPFT) yang sebagai syarat penguasaan tanah tersebut di wilayah Kecamatan Tinanggea.

Berdasarkan programyang telah dilaksanakan oleh pemerintah daerah ini, bertujuan untuk membantu masyarakat dalm memahami arti penting penguasaan dan peralihan hak atas tanah secara hukum. Namu pada prakteknya masi sebagian kecil yang melaksanakan jaul beli melalui PPAT, PPATS dan PPATK dikarenak beberapa faktor yaitu dikarenakan biaya dan tingkat kekeluargaannya yang masih tinggi.

Dapat ditarik kesimpulan bahwa berdasarkan

11 http://yusheri.blogspot.co.id/2011/05/upayapemerintah-meningkatkan-peran.html di Akses Pada 15 Juli 2017 
program-program pemerintah yang dilaksanakan sebagian besar pemerintah mengajak masyarakat untuk sadar dan tertib atauran hukum. Akan tetapi, masih sangat banyak yang belum menyadari dan tertib hukum pada prakteknya. Menarik beanang merahnya dapat kita artikan bahwa sadar dan tertib hukum nya masyarakat itu, berada pada masyarakatnya itu sendiri. Tugan dan kewenangan pemerintah hanya sebagai mengingatkan dan mengayomi masyarakat akan petingnya tertib hukum. Selanjutnya hanya masyarakatlah yang merubah kebiasan-kebiasaannya atau perbuatanperbuatannya yang menyimpang dari aturan hukum yang berlaku.

Di indonesia Proses Pendaftaran Tanah Menurut Perarutan Pemerintah ada dua ialah Pendaftaran tanah sistematik yaitu perbuatan pendaftaran yang dilakukan oleh pemerintah. Cothnya ialah Program PRONA yang dilaksanakan oleh Pemerintah. Dan Pendaftaran tanah secara sporadik adalah perbuatan oleh rakyat atas inisiatif diri sendiri. Contohnya ialah Pendaftaran atas inisiatif individu yang dibantu oleh Pejabat yang Berwenang. Seperti : PPAT, PPATS dan PPATK.

Berdasarkan Penjalasan peraturan peerintah diatas dapat di simpulakan ada dua proses pendaftaran tanah yang di kenal di indonesia yaitu Sitematis dan Sporadik yang keuda prosesnya sama. Hanya saja kalau menggunakan Pendaftaran Tanah Sistematis itu yang melaksanakan pemerintah. Sedangkan kalau menggunakan Pendaftaran Tanah poradik ialah inisiatif masyarakat yang dibantu oleh pejabat yang berwenang yaitu : PPAT, PPATS dan PPATK.

Berdasrkan prosedur aturan pendaftaran tanah yang telah di tetapkan oleh pemerintah. Diharapkan agar masyarakat melaksanakan pemindahan hak tanah. Dengan demikiian mengurangi dampak-dampak perselisihan tentang sengketa tanah

Umumnya kosep idela Bagi Masyarakat tinanggea agar melaksanakan jual beli tanah dengan PPAT atau Pejabat yang berwenang untuk menjami kepastian hukum segala perbuatan masyarakat di bidang keperdataan. Maka haruslah Pemerintah proaktif dan berperan sebagai motor penggerak dan sebagai pelindung perbuatan hukum masyarakat yang utama.

Hal-hal yang harus dilakukan oleh pemerintah agar masyarakat tertib hukum adalah penyuluhan hukum kepada masyarakat melalui pendekatan antara pemerintah dengan masyarakat, sosialisasi tentang penyadaran hukum terkait perpindahan hak tanah pada kehidupan masyarakat dan pendataan dan pembuat buku tanah pemilik hak atas tanah.

Dari hasil pembahasan di atas dapat di tarik simpulan bahwa perlunya keseriusan oleh pemerintah dalam melaksanakan program-program tersebut untuk membuat masyarakat sadar akan perbuatannya secara hukum. Karena konsep ideal itulah yang membangkitkan daya kesadaran masyarakat tersebut untuk tertib huku dalm perbuatannya yang sebagaimana seestinya dilakukan.

\section{KESIMPULAN}

Pelaksanaan Pemindahan kepemilikan tanah karena Jual Beli Hak atas Tanah dimasyarakat Kecamatan Tinanggea sebagian besar penyebab tidak melakuukan perpindahan hak milik tanah pada pejabat yang berwenang, faktor-faktor penyebabnya ialah faktor penyebab kurngnya PPAT dan PPATS, faktor penyebab biaya yang mahal, faktor penyebab karena kekeluargaan yang sangat kuat dan faktor penyebab kesadaran hukum masyarakat yang sangat rendah.

Pelaksanaan pemerintah daerah dalm upaya menyadarkan masyarakat terkhusus di Kecaatan Tinangge Kabupaten Konawe Selatan antara Kantor Pertanahan, Kantor Dinas Pendapatan Daerah, Kantor Kecamatan Tinaggea beserta jejerannya Kantor Lurah dan desa itu saling bekerja sama dan bekoordinasi. Upaya yang dilaksanakan oleh pemerintah tersebut ialah sosialisasi Dinas Pendapatan Daerah yang berkerjasama dengan kecamatan tinanggea Kabupaten konawe selatan terkait Nilai Objek Pajak ( NJOP ), Kantor kecamatan bekerjasama dengan lurah dan desa untuk menghimbau masyarakat dalam perbuatan jual beli tanah untuk memberitahukan dan melaporkan kepada pemerintah agar tidak ada perselisihan dikemudian hari dan Kecamatan dan lurah serta desa bekerjasama membuat Surat Pernyataan Penguasaan Fisik Tanah (SPPFT) yang sebagai syarat penguasaan tanah tersebut di wilayah Kecamatan Tinanggea.

Pelaksanaan pemerintah daerah dalm upaya menyadarkan masyarakat terkhusus di Kecaatan Tinangge Kabupaten Konawe Selatan antara Kantor Pertanahan, Kantor Dinas Pendapatan Daerah, 
Kantor Kecamatan Tinaggea beserta jejerannya Kantor Lurah dan desa itu saling bekerja sama dan bekoordinasi. Upaya yang dilaksanakan oleh pemerintah tersebut ialah sosialisasi Dinas Pendapatan Daerah yang berkerjasama dengan kecamatan tinanggea Kabupaten konawe selatan terkait Nilai Objek Pajak ( NJOP ), Kantor kecamatan bekerjasama dengan lurah dan desa untuk menghimbau masyarakat dalam perbuatan jual beli tanah untuk memberitahukan dan melaporkan kepada pemerintah agar tidak ada perselisihan dikemudian hari dan Kecamatan dan lurah serta desa bekerjasama membuat Surat Pernyataan Penguasaan Fisik Tanah (SPPFT) yang sebagai syarat penguasaan tanah tersebut di wilayah Kecamatan Tinanggea.

Dapat ditarik kesimpulan bahwa berdasarkan program-program pemerintah yang dilaksanakan sebagian besar pemerintah mengajak masyarakat untuk sadar dan tertib atauran hukum. Akan tetapi, masih sangat banyak yang belum menyadari dan tertib hukum pada prakteknya. Menarik beanang merahnya dapat kita artikan bahwa sadar dan tertib hukum nya masyarakat itu, berada pada masyarakatnya itu sendiri. Tugan dan kewenangan pemerintah hanya sebagai mengingatkan dan mengayomi masyarakat akan petingnya tertib hukum. Selanjutnya hanya masyarakatlah yang merubah kebiasan-kebiasaannya atau perbuatanperbuatannya yang menyimpang dari aturan hukum yang berlaku.

\section{DAFTAR PUSTAKA}

Kano Hiroyoshi, Tanah dan Pajak, Hak Milik dan Sengketa Agraria, Pustaka Sinar Harapan, Jakarta: 1997.

Budi Harsono, Hukum Agraria Indonesia, Sejarah Pembentukan Undang-Undang Pokok Agraria, Isi dan Pelaksanaannya, Jilid II, Djambatan, Jakarta: 2003.

Teguh Samudera, Hukum Pembuktian dalam Acara Perdata, Edisi Pertama, PT. Alumni, Bandung : 2004.

Teungku Muhammad Hasbi Ash Shiddieqy, HukumHukum Fiqh Islam, Pustaka Rizki Putra, Semarang : 2001.

Bintatat Sinaga, Keberadaan Girik Sebagai Bukti Surat Tanah, Grafindo, Jakarta : 1992.

Peraturan Pemerintah Pasal 37 ayat (1) Nomor 24 Tahun 1997.

Kitab Undang-Undang Perdata

Undang-Undang Pokok Agraria

http://www.invonesia.com/luas-wilayah-negaraindonesia.html di akses pada tanggal 08 April 2017.

http://yusheri.blogspot.co.id/2011/05/upayapemerintah-meningkatkan-peran.html di Akses Pada 15 Juli 2017. 